\title{
Nitrogen isotope fractionation during magma ocean degassing: tracing the composition of early Earth's atmosphere
}

\author{
C. Dalou' ${ }^{1 *}$, C. Deligny', E. Füri'
}

Abstract

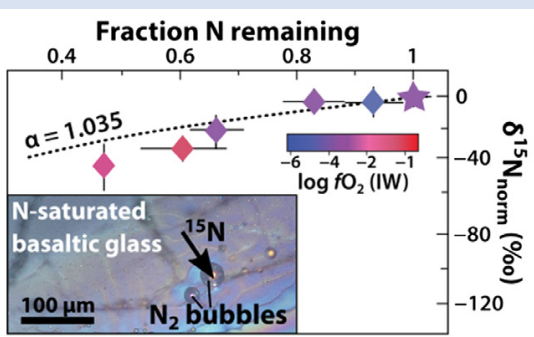

https://doi.org/l0.7185/geochemlet.2204

$798 \pm 4 \mathrm{ppm}$ at IW, controlled by $\mathrm{N}$ speciation (as determined by Raman spectroscopy), which changed from nitride ( $\pm \mathrm{N}-\mathrm{H}$ complexes) to molecular $\mathrm{N}_{2}$ with increasing $\mathrm{fO}_{2}$. Nitrogen occurs solely as $\mathrm{N}_{2}$ in the degassed gas, regardless of $f \mathrm{O}_{2}$. Nitrogen isotopic compositions (as determined by secondary ion mass spectroscopy) became significantly lighter in the degassed melt (quenched glass), down to $-41 \pm 13 \%$ relative to the initial composition (measured in an undegassed sample), following open system degassing trends (variable with $\mathrm{fO}_{2}$ conditions), indicative of Rayleigh fractionation. These findings imply that an atmosphere in equilibrium with a reduced magma ocean would be $\mathrm{N}$-depleted, whereas with increasing magma ocean $f \mathrm{O}_{2}$ conditions, the primitive atmosphere would have become more enriched in $\mathrm{N}_{2}$ gas.

Received 11 May 2021 | Accepted 13 December 2021 | Published 19 January 2022

\section{Introduction}

The accretion of reduced building blocks during Earth's formation released enough energy to at least partially melt the Earth, forming one or more magma oceans (Elkins-Tanton, 2012). The evolving nitrogen abundance in the degassing magma ocean, and thus in Earth's early atmosphere, was fundamental to the development of habitable conditions and the maintenance of the terrestrial atmosphere and biosphere (Goldblatt et al., 2009). Yet, the composition of Earth's early atmosphere remains debated: it is thought to have been either i) neutral to oxidising and composed of $\mathrm{H}_{2} \mathrm{O}, \mathrm{CO}_{2}$, and $\mathrm{N}_{2}$ if it resembled modern volcanic gases (Kasting, 1993), or ii) reducing and $\mathrm{CH}_{4}{ }^{-}$and $\mathrm{NH}_{3}$-rich if it degassed from the reduced materials that formed the Earth (Zahnle et al., 2020), based on geochemical evidence that magma ocean degassing contributed to the formation of the Hadean atmosphere (see review by Gaillard et al., 2021). Therefore, reconstructing nitrogen degassing during Earth's magma ocean stage(s) is critical to constraining the composition of the early atmosphere.

Nitrogen is often considered to be an inert molecule $\left(\mathrm{N}_{2}\right)$ and expected to behave somewhat like noble gases. However, recent works have shown that nitrogen is not always chemically inert and occurs as various species $\left(\mathrm{N}^{3-}, \mathrm{NH}_{3}, \mathrm{NH}_{2}^{-}, \mathrm{NH}^{2-}\right.$ and $\mathrm{N}_{2}$ ) in silicate melts (Mikhail and Sverjensky, 2014; Dalou et al., 2019a; Mosenfelder et al., 2019; Boulliung et al., 2020; Grewal et al., 2020) and fluids (Li and Keppler, 2014). The speciation and solubility of nitrogen primarily depend on oxygen fugacity (Libourel et al., 2003; Boulliung et al., 2020; Bernadou et al., 2021), which increased during the evolution of Earth's magma ocean (Frost et al., 2008). Thus, the rate of nitrogen degassing and the reactions involved must have evolved similarly over geological time.

Nitrogen isotopic compositions, conventionally normalised to the present atmospheric value and reported as $\delta^{15} \mathrm{~N}[\% \mathrm{o}]=\left[\left(\frac{{ }^{15} \mathrm{~N} /{ }^{14} \mathrm{~N}_{\mathrm{sample}}}{{ }^{15} \mathrm{~N} /{ }^{14} \mathrm{~N}_{\mathrm{atm} \mathrm{N}}}\right)-1\right] \cdot 1,000$, are useful for reconstructing Earth's $\mathrm{N}$ degassing history. For instance, the range of $\delta^{15} \mathrm{~N}$ values observed in Archean diamonds corresponds to that in present day diamonds and mid-ocean ridge basalts (MORBs), implying that the mantle $\delta^{15} \mathrm{~N}$ value has not evolved since the Archean (Cartigny and Marty, 2013). This is consistent with the observation that diffusion controlled $\mathrm{N}_{2}$ degassing from the present day mantle, which is expected to preferentially segregate ${ }^{14} \mathrm{~N}$ into the atmosphere following Graham's law (i.e. the rate of diffusion/effusion of a gas is inversely proportional to the square root of its molecular weight; Javoy et al., 1986), is limited to isotopic fractionations of 1-1.5\%o (Marty and Dauphas, 2003). However, Rayleigh models of equilibrium MORB degassing (Javoy et al., 1986; Cartigny et al., 2001) only consider the reaction $\mathrm{N}_{2}$ (magma) $\leftrightarrow \mathrm{N}_{2}$ (gas). This reaction has been experimentally determined at oxygen fugacity conditions $\left(\mathrm{fO}_{2}\right)>\mathrm{IW}$ (Libourel

1. Université de Lorraine, CNRS, CRPG, F-54000 Nancy, France

* Corresponding author (email: celia.dalou@univ-lorraine.fr) 
et al., 2003; Boulliung et al., 2020), which applies to present day conditions of upper mantle degassing. However, because the integrated $\mathrm{fO}_{2}$ during core formation was closer to IW-2 (Frost et al., 2008), this reaction does not hold for the more reduced $\mathrm{N}$ species present in the magma ocean. Larger $\mathrm{N}$ isotopic fractionations are expected under reducing conditions at which $\mathrm{N}$ does not behave inertly. Therefore, quantifying $\mathrm{N}$ isotopic fractionations under conditions at which $\mathrm{N}$ dissolves in magmas as nitride or $\mathrm{N}-\mathrm{H}$ complexes is prerequisite to quantitatively modelling the evolution of $\mathrm{N}$ concentrations and isotopic compositions during the formation of the Hadean atmosphere.

\section{Degassing Experiments and Results}

To establish the effect of $\mathrm{fO}_{2}$ on the $\mathrm{N}$ degassing rate and identify $\mathrm{N}$ degassing reactions that may have occurred in the Earth's magma ocean, we determined the $\mathrm{N}$ concentration, speciation, and isotopic fractionation of a basaltic komatiite (used as magma ocean analogue melt) during degassing at $1.5 \mathrm{GPa}$ and $1550{ }^{\circ} \mathrm{C}$ in pure forsterite capsules. Degassing experiments were performed using a series of Fe-free primitive basalts in which we explored $\mathrm{fO}_{2}$ conditions ranging from IW to IW-4.2 (Table 1). These $\mathrm{fO}_{2}$ conditions were not determined in the Fe-free experiments, but only estimated afterwards from the IW reaction in equivalent Fe-bearing runs (see Supplementary Information). The initial ${ }^{15} \mathrm{~N} /{ }^{14} \mathrm{~N}$ ratio of the starting material was $0.946 \pm$ 0.003, as determined in sample V133-PB4N2Si (Table 1), in which the initial $\mathrm{N}$ content was equal, within errors, to that measured after the experiment. Nitrogen was saturated in five experiments, as evidenced by bubbles in the quenched glass and/or surrounding forsterite (Fig. 1, Table 1).

The major element compositions of the silicate glasses were measured by electron microprobe (Table S-1). Nitrogen concentrations and ${ }^{15} \mathrm{~N} /{ }^{14} \mathrm{~N}$ ratios were determined by secondary ion mass spectrometry (SIMS) using the CAMECA IMS 1280-HR2 at the CRPG (Table 1). On each sample, four to six spot analyses of ${ }^{14} \mathrm{~N}^{16} \mathrm{O}^{-}$and ${ }^{15} \mathrm{~N}^{16} \mathrm{O}^{-}$were performed (see Supplementary Information). Measured $\mathrm{N}$ concentrations were homogeneous (i.e. with standard deviations below $10 \%$ ). N concentrations at $1.5 \mathrm{GPa}$ and $1550{ }^{\circ} \mathrm{C}$ decreased from 13,481 \pm $735 \mathrm{ppm}$ (at IW-4.2) to $798 \pm 4 \mathrm{ppm}$ (at IW; Fig. 2a). In N saturated samples (as attested by the presence of bubbles), $\mathrm{N}$ concentrations decreased from $13,481 \pm 735 \mathrm{ppm}$ (at IW-4.2) to 3,084 $\pm 377 \mathrm{ppm}$ (at IW-1). This decrease of N solubility with increasing $\mathrm{fO}_{2}$ is consistent with observations in silicate melts at 1 atm (Libourel et al., 2003; Boulliung et al., 2020) and modelled at pressures up to $1 \mathrm{GPa}$ (Bernadou et al., 2021). Yet, the N solubilities observed herein are up to three orders of magnitude higher than those in a similar melt composition and at similar

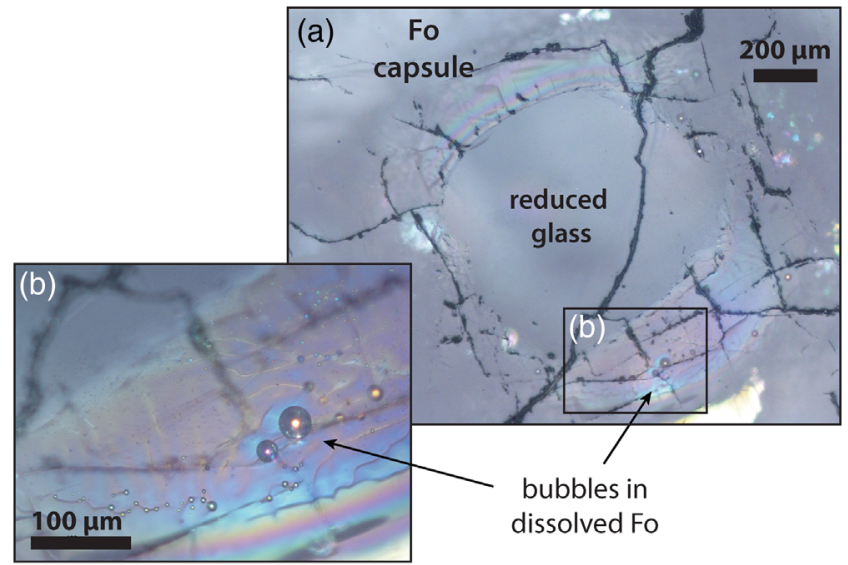

Figure 1 Optical microscope photograph of sample V125-PB8N, which contains $13,342 \pm 841 \mathrm{ppm} \mathrm{N}$ and lost $15 \%$ of its initial $\mathrm{N}$ content by degassing. The reduced glasses contain aligned microscopic bubbles, likely produced during quenching. Large bubbles, produced by degassing at high pressure and high temperature, are located within a rim of dissolved forsterite (Fo) at the border between the glass and the forsterite capsule. The dissolved forsterite contains negligible amounts of $\mathrm{N}(2 \pm 2 \mathrm{ppm})$.

temperatures at $1 \mathrm{~atm}$ (Boulliung et al., 2020) and one order of magnitude higher than those at $0.08 \mathrm{GPa}$ (Bernardou et al., 2021), consistent with the effect of pressure on $N$ solubility described by Bernardou et al. (2021). The variation of $\mathrm{N}$ solubilities with $\mathrm{fO}_{2}$ is directly related to changes of $\mathrm{N}$ speciation in the silicate melts, which were determined by Raman spectroscopy (see Supplementary Information). Around IW-4 and below, $\mathrm{N}$ is very soluble because it is dissolved as nitride, forming $\mathrm{Si}-\mathrm{N}$ bonds with the silicate network; indeed, in very $\mathrm{N}$-rich samples (>1 wt. \% N), Si-N vibrations around $800 \mathrm{~cm}^{-1}$ were observed (Fig. 2b). In less reduced samples $\left(\mathrm{fO}_{2}>\mathrm{IW}-4\right), \mathrm{N}$ is mostly dissolved as N-H complexes (Fig. 2c), and above IW-2, $\mathrm{N}$ is also dissolved as molecular $\mathrm{N}_{2}$ (Fig. 2d). Consistent with previous studies (Mosenfelder et al., 2019; Grewal et al., 2020), $\mathrm{N}$ speciation in the silicate glasses controls $\mathrm{N}$ solubility variations with $\mathrm{fO}_{2}$ conditions. Depending on initial $\mathrm{N}$ content and $\mathrm{fO}_{2}$, the fraction of N degassed varied from 7 to $53 \%$. Samples V152PB0.5N and V149-PB1N did not show any evidence of degassing, i.e. no bubbles were observed in the glass or the forsterite rim, but lost 12 and $32 \%$ of their initial $\mathrm{N}$, respectively, likely due to diffusion through cracks formed in the forsterite capsule during compression.

The use of ${ }^{15} \mathrm{~N}$ spiked samples permits us to obtain precise ${ }^{15} \mathrm{~N} /{ }^{14} \mathrm{~N}$ ratios in the silicate (with low uncertainties of $0.1 \%$ on

Table 1 Experimental results on nitrogen contents and isotope fractionation in silicate glasses.

\begin{tabular}{|l|c|c|c|c|c|c|c|}
\hline \multicolumn{1}{|c|}{ Exp ID } & $\begin{array}{c}\text { Estimated } \\
\mathrm{fO}_{2}(\boldsymbol{\Delta} \mathrm{IW})\end{array}$ & $\begin{array}{c}\text { Initial N } \\
\text { content }(\mathrm{ppm})\end{array}$ & $\begin{array}{c}\text { Measured N } \\
\text { content }(\mathrm{ppm})\end{array}$ & $\begin{array}{c}\mathrm{F} \text { (remaining } \\
\mathrm{N} \text { fraction) }\end{array}$ & $\begin{array}{c}\text { Measured } \\
15 \mathrm{~N} /{ }^{14} \mathrm{~N} \text { ratios }\end{array}$ & $\begin{array}{c}\text { Calculated } \boldsymbol{\delta}^{15} \mathrm{~N} \\
\text { normalised }(\%)\end{array}$ & $\begin{array}{c}\text { Bubbles } \\
\text { present }\end{array}$ \\
\hline V152-PB05N & 0.0 & 910 & $798 \pm 4$ & $0.88 \pm 0.01$ & $0.871 \pm 0.005$ & $-79 \pm 8$ & \\
V149-PB1N & -0.3 & 1945 & $1316 \pm 16$ & $0.68 \pm 0.01$ & $0.845 \pm 0.028$ & $-107 \pm 34$ & $-32 \pm 6$ \\
V129-PB2N & -1.0 & 5075 & $3084 \pm 377$ & $0.61 \pm 0.07$ & $0.916 \pm 0.003$ & $\checkmark$ \\
V148-PB4N & -2.3 & 10435 & $4914 \pm 102$ & $0.47 \pm 0.01$ & $0.907 \pm 0.011$ & $-41 \pm 13$ & $\checkmark$ \\
V133-PB4N2Si & -2.6 & 8371 & $8335 \pm 194$ & $1.00 \pm 0.02$ & $0.946 \pm 0.003$ & $0 \pm 6$ & $\checkmark$ \\
V125-PB8N & -3.3 & 16076 & $13342 \pm 841$ & $0.83 \pm 0.05$ & $0.925 \pm 0.004$ & $-5 \pm 7$ & $\checkmark$ \\
V151-PB6N3Si & -3.4 & 11353 & $7534 \pm 526$ & $0.66 \pm 0.05$ & $0.926 \pm 0.007$ & $-21 \pm 10$ & $\checkmark$ \\
V150-PB8N6Si & -4.2 & 14609 & $13481 \pm 735$ & $0.93 \pm 0.05$ & $0.941 \pm 0.006$ & $-5 \pm 9$ & $\checkmark$ \\
\hline
\end{tabular}


(a)

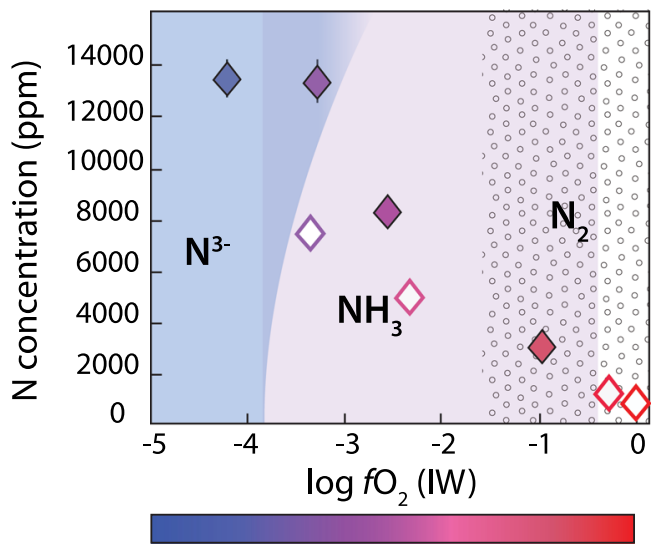

(b)

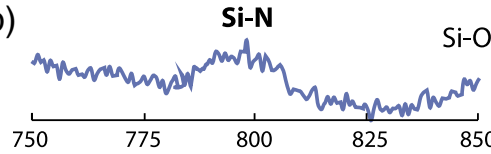

(c)

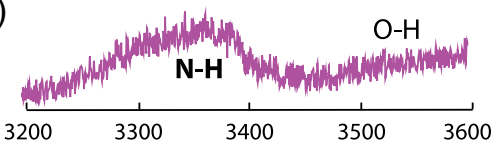

(d)

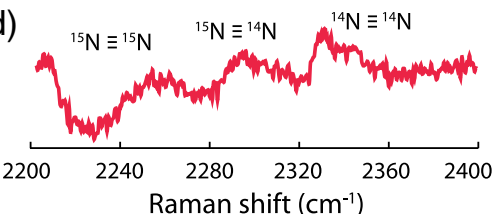

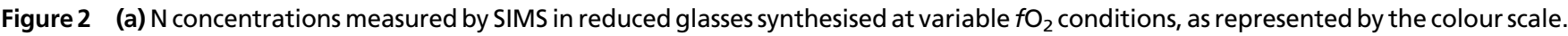
Open symbols represent samples that did not reach saturation. Raman spectra show (b) Si-N vibrations in sample V125-PB8N and also observed in sample V150-PB8N6Si, (c) N-H vibrations in sample V148-PB4N and also observed in all samples between IW-4 and IW-1 (pink shaded area in (a)), and (d) $\mathrm{N}_{2}$ vibrations in sample V141-PB1N, corrected for air contamination, and also observed in samples $\mathrm{V} 152-\mathrm{PB} 05 \mathrm{~N}$ and V129-PB2N.

average). With increasing fraction of degassed $\mathrm{N},{ }^{15} \mathrm{~N} /{ }^{14} \mathrm{~N}$ ratios decreased from $0.946 \pm 0.003$ in the undegassed sample to $0.907 \pm 0.011$ in the most degassed sample (53\% of initial $\mathrm{N}$ lost). The ${ }^{15} \mathrm{~N} /{ }^{14} \mathrm{~N}$ ratios were normalised to the initial ${ }^{15} \mathrm{~N} /{ }^{14} \mathrm{~N}$ ratio of the undegassed glass V133-PB4N2Si $(0.946 \pm 0.003)$ and expressed as $\delta^{15} \mathrm{~N}_{\text {norm }}$ as:

$$
\delta^{15} \mathrm{~N}_{\text {norm }}[\% \mathrm{o}]=\left[\left(\frac{{ }^{15} \mathrm{~N} /{ }^{14} \mathrm{~N}_{\text {melt }}}{{ }^{15} \mathrm{~N} /{ }^{14} \mathrm{~N}_{\text {initial }}}\right)-1\right] \cdot 1,000 . \quad \text { Eq. } 1
$$

These normalised values are not calculated relative to the atmospheric $\mathrm{N}$ isotopic composition $\left({ }^{15} \mathrm{~N} /{ }^{14} \mathrm{~N}_{\text {air }}=0.003676\right)$ and cannot be directly compared to the $\delta^{15} \mathrm{~N}$ values of natural samples.

\section{Degassing Models of $\mathbf{N}$ Isotopic Fractionation under Reduced Conditions}

The normalised $\mathrm{N}$ isotopic composition of the glasses decreases from $0 \%$ in the undegassed glass to $-41 \pm 13 \%$ in the most degassed glass (Fig. 3). Although this $\delta^{15} \mathrm{~N}$ variation is opposite to that observed during MORB degassing (Cartigny et al., 2001), it is consistent with glasses becoming isotopically lighter with increased degassing as observed for $\mathrm{H}, \mathrm{C}$, and $\mathrm{S}$ in natural settings (Supplementary Information). An open system degassing model, in which the exsolved vapour is immediately removed from contact with the melt during degassing, is suitable with the presence of gas bubbles within the dissolved forsterite rims (Fig. 1):

$$
\delta^{15} \mathrm{~N}_{\text {glass }}=\delta^{15} \mathrm{~N}_{\text {initial }}+(F-1) 1,000 \ln \alpha,
$$

where $\delta^{15} \mathrm{~N}_{\text {initial }}$ is the "normalised initial" isotopic composition of the melt (here $0 \%$; sample V133-PB4N2Si), F is the fraction of $\mathrm{N}$ remaining in the melt, and $\alpha$ is the isotopic fractionation factor. In this case, open system degassing occurs in a finite $\mathrm{N}$ budget, conforming to a Rayleigh process (Equation 2).

In bubbles for which the gas pressure was sufficient to obtain a Raman signal above the noise, $\mathrm{N}$ was observed only as $\mathrm{N}_{2}$, even in very reduced samples in which $\mathrm{N}$ was dissolved as N-H complexes (V148-PB4N) and/or nitrides (V125-PB8N).
Therefore, we propose that at IW to IW-1, the N degassing reaction is:

$$
\mathrm{N}_{2 \text { (magma) }} \leftrightarrow \mathrm{N}_{2 \text { (gas) }}
$$

Had the least reduced samples (V152-PB0.5N and V149PB1N) not been affected by diffusion through cracks, they would be expected to degas following Equation 3 , since $\mathrm{N}_{2}$ is the only $\mathrm{N}$ species dissolved in those melts. In contrast, under more reduced conditions, $\mathrm{N}$ degassed as (e.g., Dalou et al., 2019a):

$$
\begin{aligned}
& 2 \mathrm{NH}_{3 \text { (magma) }} \leftrightarrow \mathrm{N}_{2 \text { (gas) }}+3 \mathrm{H}_{2 \text { (gas) }}, \quad \text { Eq. } 4 \\
& 2 \mathrm{SiN}_{(\text {magma })}+4 \mathrm{OH}_{\text {(magma) }} \leftrightarrow 2 \mathrm{SiO}_{2 \text { (magma) }}+\mathrm{N}_{2 \text { (gas) }}+2 \mathrm{H}_{2 \text { (gas) }} .
\end{aligned}
$$

The fugacities of the relevant $\mathrm{N}$ species cannot be calculated at present due to a lack of thermodynamic data (see Supplementary Information).

To understand how $\mathrm{N}$ speciation can affect gas-melt $\mathrm{N}$ isotopic fractionation, we derived the basic equation for equilibrium isotopic fractionation for stable isotopes (Young et al., 2015):

$$
\begin{aligned}
& \Delta^{15} \mathrm{~N}^{\text {gas }- \text { melt }}=\frac{1,000}{24} \cdot\left(\frac{h}{k_{\mathrm{b}} T}\right)^{2}\left(\frac{\Delta m}{m_{14} m_{15}}\right) \\
& \times\left[\left(\nu_{\mathrm{N}}^{\text {gas }^{2}}-\nu_{\mathrm{N}}^{\text {melt }}{ }^{2}\right)\left(\mu_{\mathrm{N}}^{\text {gas }}-\mu_{\mathrm{N}}^{\text {melt }}\right)\right], \quad \text { Eq. } 6 \\
& \alpha=\exp \left(\Delta^{15} \mathrm{~N}^{\text {gas }- \text { melt }} / 1,000\right),
\end{aligned}
$$

where $h$ is Planck's constant $\left(J \cdot \mathrm{K}^{-1}\right), k_{\mathrm{b}}$ is the Boltzmann constant $\left(\mathrm{J} . \mathrm{Hz}^{-1}\right), T$ is temperature $(\mathrm{K}), v^{\text {gas }}$ and $v^{\text {melt }}$ denote the Raman vibration modes $(\mathrm{Hz})$ of $\mathrm{N}$ species in the gas and silicate phases, respectively, and $\mu_{\mathrm{N}}$ is the reduced mass of the $\mathrm{N}$-bearing molecule. Using this expression, we calculated that the $\mathrm{N}$ isotopic fractionation factor at $1550{ }^{\circ} \mathrm{C}$ is 0.999 for degassing by Equation 3, and, under more reduced conditions, 1.005 for Equation 4, both in agreement with Hanschmann (1981), and 0.998 for Equation 5. These equilibrium fractionation factors cannot explain the variation of $\delta^{15} \mathrm{~N}_{\text {norm }}$ values observed in the degassed samples; the high isotopic fractionation undergone by these degassed melts rather suggests a kinetic process. Indeed, such large kinetic nitrogen isotopic effects have also 

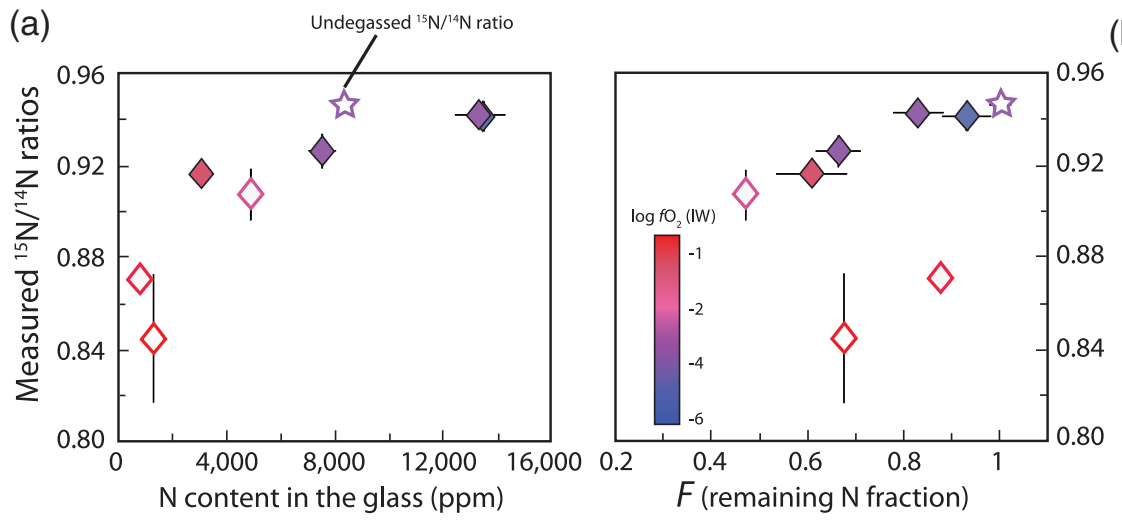

(b)

(c)
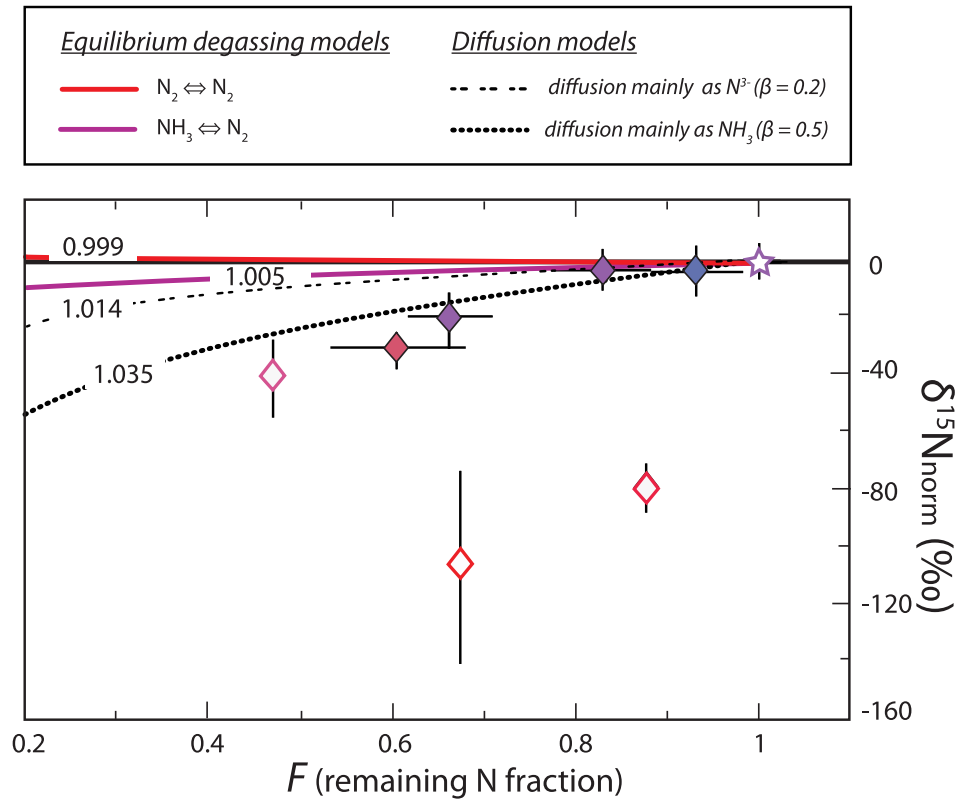

Figure 3 (a) ${ }^{15} \mathrm{~N} /{ }^{14} \mathrm{~N}$ ratios as a function of $\mathrm{N}$ content in glass, and (b) ${ }^{15} \mathrm{~N} /{ }^{14} \mathrm{~N}$ ratios, and (c) $\delta^{15} \mathrm{~N}$ values normalised to the initial value (see text) in reduced glasses as a function of $F$, the fraction of $\mathrm{N}$ remaining. $F$ was calculated by dividing the measured $\mathrm{N}$ content in the glass by the estimated $\mathrm{N}$ content added to the starting material. Because all starting compositions were prepared from the same initial $\mathrm{N}$-rich powder by variable mixes with a N-free powder, the initial ${ }^{15} \mathrm{~N} /{ }^{14} \mathrm{~N}$ ratios were the same in all starting materials. The degassing models are described in the text.

been observed in mantle-derived samples (Yokochi et al., 2009). However, kinetic fractionation via evaporation results in increasingly heavy isotopic values (Saal and Hauri, 2021), opposite to our observations (Fig. 3c). The observed large isotopic fractionation may thus be explained by a variable diffusion process depending on $\mathrm{N}$ speciation, and therefore on $\mathrm{fO}_{2}$ conditions. The magnitude of diffusive $\mathrm{N}$ isotopic fractionation during degassing is similar to that observed in natural high pressurehigh temperature peridotitic systems ( $>25 \%$; Yokochi et al., 2009; see Supplementary Information). Such a fractionation effect can be estimated from the ratio of the diffusion coefficients $(D)$ of ${ }^{14} \mathrm{~N}$ and ${ }^{15} \mathrm{~N}$, expressed as a function of their mass $(m)$ : $\frac{D_{14 \mathrm{~N}}}{D_{15 \mathrm{~N}}}=\left(\frac{\mathrm{m}_{15 \mathrm{~N}}}{\mathrm{~m}_{14 \mathrm{~N}}}\right)^{\beta}$, where $\beta$ is an empirical parameter with values between 0 and 0.5 that positively correlates with the diffusivity of the ion in silicate melts (Van Orman and Krawczynski, 2015). Hence, $\mathrm{N}_{2}$ and $\mathrm{NH}_{3}$, which diffuse rapidly through silicate melts relative to $\mathrm{Si}$, have a large isotopic effect (high $\beta$ ), whereas $\mathrm{N}^{3-}$, which is bonded to Si, diffuses slowly (Boulliung et al., 2021) and has a smaller isotopic effect (low $\beta$ ). Good fits to our data are $\beta=0.2$ for $\mathrm{N}$ diffusing as $\mathrm{N}^{3-}$ and $\beta=0.5$ for $\mathrm{N}$ as $\mathrm{NH}_{3}$ (Fig. 3c). A simple diffusion process cannot explain the extremely large fractionation in undegassed samples (V152-PB0.5N and V149-PB1N), unless the diffusion of ${ }^{14} \mathrm{~N}$ and ${ }^{15} \mathrm{~N}$ is decoupled, with ${ }^{15} \mathrm{~N}$ favouring the stiffest bonds $\left(\mathrm{N}_{2}\right)$ and diffusing significantly faster than ${ }^{14} \mathrm{~N}$, favouring weaker $\mathrm{N}-\mathrm{H}$ bonds in $\mathrm{NH}_{3}$. It is possible that $\mathrm{N}_{2}$ diffusion in these melts is faster than degassing and controls the isotopic fractionation mechanism in these undegassed samples.

\section{Evolution of the $\mathrm{N}$ Composition of Earth's Primitive Atmosphere}

Figure 3 shows that $\mathrm{fO}_{2}$ conditions determine N solubility and, therefore, the fraction of $\mathrm{N}$ degassed and the isotopic fractionation trends. Our results suggest that the upper layer of Earth's magma ocean degassed $\mathrm{N}$ as $\mathrm{N}_{2}$, regardless of $\mathrm{fO}_{2}$ conditions, but that the intensity of $\mathrm{N}_{2}$ degassing increased as the magma ocean became less reduced. This is in agreement with the recent model of Sossi et al. (2020), which predicts that Earth's prebiotic atmosphere was dominated by $\mathrm{CO}_{2}$ and $\mathrm{N}_{2}$ gases.

Whether $\mathrm{N}$ was dissolved in the magma ocean as nitride, ammonia, or both, $\mathrm{N}$ loss depleted the surface or upper parts of the magma ocean in ${ }^{15} \mathrm{~N}$ relative to the atmosphere. This could have produced the currently observed isotopic differences between the ${ }^{15} \mathrm{~N}$-depleted mantle $\left(\delta^{15} \mathrm{~N}=-5 \pm 2 \%\right.$ in diamonds and MORBs) and the ${ }^{15} \mathrm{~N}$-enriched surface $\left(\delta^{15} \mathrm{~N}=+6 \%\right.$ in 
sediments and $\delta^{15} \mathrm{~N}=0 \%$, by definition, in the atmosphere) (Cartigny and Marty, 2013). Other explanations of the $\mathrm{N}$ isotopic distribution among terrestrial reservoirs include $i$ ) recycling (subduction) of surficial materials, and ii) core-mantle differentiation (Li et al., 2016; Dalou et al., 2019b) However, Labidi et al. (2020) recently showed that $\mathrm{N}$ recycling is inefficient. How core-mantle differentiation would have affected the upper layer of the magma ocean and thus the present day depleted mantle, would have depended on the depth of the magma ocean and the efficiency of post-magma ocean convection to homogenise the $\delta^{15} \mathrm{~N}$ value of the mantle; thus this process remains disputable.

\section{Acknowledgements}

We thank Johan Villeneuve for his assistance and support during SIMS analyses, Jean-Luc Devidal for performing microprobe analyses on silicate glasses, and Marie-Camille Caumon for her help with Raman spectroscopy analyses. We are grateful to Robert Dennen for English editing. We thank reviewers Paolo Sossi and Sami Mikhail for their comments that greatly improved the manuscript, and editor Helen Williams for handling the manuscript. This work was supported by the European Research Council under the European Union's Horizon 2020 research and innovation program (Grant Agreement no. 715028). This is CRPG contribution 2812.

\section{Editor: Helen Williams}

\section{Additional Information}

Supplementary Information accompanies this letter at https:// www.geochemicalperspectivesletters.org/article2204.

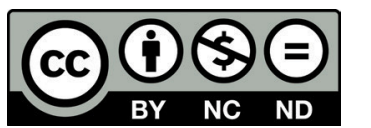

(C) 2022 The Authors. This work is distributed under the Creative Commons Attribution NonCommercial No-Derivatives 4.0 License, which permits unrestricted distribution provided the original author and source are credited. The material may not be adapted (remixed, transformed or built upon) or used for commercial purposes without written permission from the author. Additional information is available at https://www. geochemicalperspectivesletters.org/copyright-and-permissions.

Cite this letter as: Dalou, C., Deligny, C., Füri, E. (2022) Nitrogen isotope fractionation during magma ocean degassing: tracing the composition of early Earth's atmosphere. Geochem. Persp. Let. 20, 27-31. https://doi.org/10.7185/geochemlet.2204

\section{References}

Bernadou, F., Gaillard, F., Füri, E., Marrocchi, Y., SlodczyK, A. (2021) Nitrogen solubility in basaltic silicate melt-Implications for degassing processes. Chemical Geology 573, 120192

Boulliung, I., Füri, E., Dalou, C., Tissandier, L., Zimmermann, L., Marrocchi, Y (2020) Oxygen fugacity and melt composition controls on nitrogen solubility in silicate melts. Geochimica et Cosmochimica Acta 284, 120-133.

Boulliung, J., Dalou, C., Tissandier, L., Füri, E., Marrocchi, Y. (2021) Nitrogen diffusion in silicate melts under reducing conditions. American Mineralogist $106,662-666$.

Cartigny, P., MarTy, B. (2013) Nitrogen isotopes and mantle geodynamics: The emergence of life and the atmosphere-crust-mantle connection. Elements 9, 359-366.

Cartigny, P., Jendrzejewski, N., Pineau, F., Petit, E., Javoy, M. (2001) Volatile (C, N, Ar) variability in MORB and the respective roles of mantle source heterogeneity and degassing: the case of the Southwest Indian Ridge. Earth and Planetary Science Letters 194, 241-257.

Dalou, C., Hirschmann, M.M., Jacobsen, S.D., Le Lose, C. (2019a) Raman spectroscopy study of C-O-H-N speciation in reduced basaltic glasses: Implications for reduced planetary mantles. Geochimica et Cosmochimica Acta 265, 32-47.

Dalou, C., Füri, E., Deligny, C., Piani, L., Caumon, M.C., Laumonier, M. Boulliung, J., Edén, M. (2019b) Redox control on nitrogen isotope fractionation during planetary core formation. Proceedings of the National Academy of Sciences 116, 14485-14494.

ElKins-TANTON, L.T. (2012) Magma oceans in the inner solar system. Annual Review of Earth and Planetary Sciences 40, 113-139.

Frost, D.J., Mann, U., Asahara, Y., Rubie, D.C. (2008) The redox state of the mantle during and just after core formation. Philosophical Transactions of the Royal Society A: Mathematical, Physical and Engineering Sciences 366, 4315-4337.

Gaillard, F., Bouhifd, M.A., Füri, E., Malavergne, V., Marrocchi, Y., Noack, L., Ortenzi, G., Roskosz, M., Vulpius, S. (2021) The Diverse Planetary Ingassing/Outgassing Paths Produced over Billions of Years of Magmatic Activity. Space Science Reviews 217, 1-54.

Goldblatt, C., Claire, M.W. Lenton, T.M., Matthews, A.J., Watson, A.J., ZAHNLE, K.J. (2009) Nitrogen-enhanced greenhouse warming on early Earth. Nature Geosciences 2, 891-896.

GreWAL, D.S., DAsGupta, R., FARNelL, A. (2020) The speciation of carbon, nitrogen, and water in magma oceans and its effect on volatile partitioning between major reservoirs of the Solar System rocky bodies. Geochimica et Cosmochimica Acta 280, 281-301.

Hanschmann, G. (1981) Quantum chemical calculations of isotope effects in nitrogen-containing molecules. ZFI-Mitteilungen 41, 19-39.

Javoy, M., Pineau, F., Delorme, H. (1986) Carbon and nitrogen isotopes in the mantle. Chemical Geology 57, 41-62.

KASTING, J.F. (1993) Earth's early atmosphere. Science 259, 920-926.

Labidi, J., Barky, P.H., Bekaert, D.V., Broadley, M.W., Marty, B., Giunta, T., Warr, O., Sherwood lollar, B., Fisher, T.B., Avice, G., Caracausi, A., Ballentine, C.J., Halldórsson, S.A., Stefánsson, A., Kurz, M.D., KoHL, I.E., Young, E.D. (2020) Hydrothermal ${ }^{15} \mathrm{~N}^{15} \mathrm{~N}$ abundances constrain the origins of mantle nitrogen. Nature 580, 367-371.

LI, Y., KeppleR, H. (2014) Nitrogen speciation in mantle and crustal fluids. Geochimica et Cosmochimica Acta 129, 13-32.

Li, Y.F., MARTy, B., ShcheKa, S., Zimmermann, L., Keppler, H. (2016) Nitrogen isotope fractionation during terrestrial core-mantle separation. Geochemical Perspectives Letters 2, 138-147.

Libourel, G., Marty, B., Humbert, F. (2003) Nitrogen solubility in basaltic melt. Part I. Effect of oxygen fugacity. Geochimica et Cosmochimica Acta 67, 4123-4135.

MARTY, B., DAUPHAS, N. (2003) The nitrogen record of crust-mantle interaction and mantle convection from Archean to present. Earth and Planetary Sciences Letters 206, 397-410.

MiKHAIL, S., SVERJENSKY, D.A. (2014) Nitrogen speciation in upper mantle fluids and the origin of Earth's nitrogen-rich atmosphere. Nature Geosciences 7, 816-819.

Mosenfelder, J.L., Von Der Handt, A., Füri, E., Dalou, C., Hervig, R.L., Rossman, G.R., HiRSCHMANN, M.M. (2019) Nitrogen incorporation in silicates and metals: Results from SIMS, EPMA, FTIR, and laser-extraction mass spectrometry. American Mineralogist 104, 31-46.

VAn Orman, J.A., KRAWCZYNSKI, M.J. (2015) Theoretical constraints on the isotope effect for diffusion in minerals. Geochimica et Cosmochimica Acta 164, 365-381.

SAAL, A.E., HAurI, E.H. (2021) Large sulfur isotope fractionation in lunar volcanic glasses reveals the magmatic differentiation and degassing of the Moon. Science Advances 7, eabe4641.

Sossi, P.A., Burnham, A.D., Badro, J., Lanzirotti, A., Newville, M., O’Neill, H.S.C. (2020) Redox state of Earth's magma ocean and its Venus-like early atmosphere. Science Advances 6, eabd1387.

Yokochi, R., Marty, B., Chazot, G., Burnard, P. (2009) Nitrogen in peridotite xenoliths: Lithophile behavior and magmatic isotope fractionation. Geochimica et Cosmochimica Acta 73, 4843-4861.

Young, E.D., Manning, C.E., Schauble, E.A., Shahar, A., Macris, C.A., Lazar, C., JORDAN, M. (2015) High-temperature equilibrium isotope fractionation of non-traditional stable isotopes: Experiments, theory, and applications. Chemical Geology 395, 176-195.

Zahnle, K.J., Lupu, R., CatLing, D.C., Wogan, N. (2020) Creation and evolution of impact-generated reduced atmospheres of early Earth. Planetary Science Journal 1, 11 